\title{
Contents
}

Acknowledgments

ix

PROLOGUE

Her Voice Can Be Heard

xiii

CHAPTER 1

Inquiry and Epiphany

3

CHAPTER 2

Born in Slavery: The Master, the Mistress, and Their Chattel

18

CHAPTER 3

The Berkeleys, a Slave Named Harriet Bishop, and Her Daughter, Sarah

38

CHAPTER 4

Slavery's Chain Done Broke at Last

53

CHAPTER 5

Colorado and the Promise of Freedom

66

CHAPTER 6

From Denver's Bottoms to P. T. Barnum's Town

82 
CHAPTER 7

Education, Politics, and Leisure

99

CHAPTER 8

The Frontier in Our Souls

120

CHAPTER 9

School, Community, and Love Lost

150

CHAPTER 10

A Fly in the Buttermilk: Colorado and the World of Higher Education

167

CHAPTER 11

“Goin’ to Kansas City”: Education and Baseball

190

CHAPTER 12

It's Mister Jones, If You Please

200

CHAPTER 13

Chicago, Take Two

214

CHAPTER 14

"Lincoln Was a Republican, That's All I Need to Know"

227

CHAPTER 15

Coming Home and Going Home

234

EPILOGUE

The End of the Living Line

255

Notes

267

Index

305 


\title{
Prologue \\ Her Voice Can Be Heard
}

\author{
Just as a tree without roots is dead, a people with- \\ out history or culture becomes a dead people. \\ - MALCOLM X
}

If historians of the American West and of the African American experience have ignored the contributions of western blacks, they have been especially negligent in chronicling the presence of black women on the western frontier.

- GLENDA RILEY

Lucile Berkeley Buchanan Jones never sought the spotlight or public recognition. Instead, she chose a life as hushed as falling autumn leaves. As I began to unravel the woman she was, I developed a passionate curiosity about the remarkable life she led. Born in a barn to emancipated slaves from Virginia near the South Platte River in Denver, Colorado, on June 13, 1884, toward the end of the Victorian era, she would die on November 13, 1989, as the Decade of Greed and the "Me" Generation came to a close.

Through ten-and-a-half decades, Lucile rejected, with prejudice, the traditional domestic roles set aside for Black women, and instead chose a career path that would require courage in the face of pernicious Jim Crow laws. She was confronted with the visceral reality of lynch mob violence when on the evening of June 19, 1913, less than a mile from where she lived in Hot Springs, Arkansas, a mob lynched twenty-one-year-old William Norman. His body was riddled with bullets, his corpse burned and left at the site as Whites continued to celebrate his death the next day, sifting through the ashes and collecting bones as souvenirs. ${ }^{1}$ Like the fictional character Forrest Gump, in the 1994 film of the same name, Lucile witnessed spectacular and inspiring moments in US history. In 1893 she celebrated the hard work of Colorado's Black and White suffragettes, as the women 
of Colorado received the right to vote through popular referendum twenty-seven years before national women's suffrage. A year later, she witnessed Denver's Black suffragist Elizabeth Piper Ensley rallying Black women to the polls.

In 1924, while in Kansas City, she attended the inaugural Negro League World Series between the National Negro League champions, the Kansas City Monarchs, and the Eastern Colored League champions, the Hilldale Daisies of Darby, Pennsylvania. In 1933, when Thomas Andrew Dorsey_credited as "the father of gospel music" 2 and who wrote such popular songs as "Peace in the Valley" and "Take My Hand, Precious Lord"-organized the National Convention of Gospel Choirs and Choruses in Chicago, where Lucile served as the organization's first recording secretary.

She was fluent in German, a language she began studying in Colorado in 1905, and also read Latin. In the 1920s, while teaching at the all-Black Lincoln High School in Kansas City, Missouri, she created the school's first student newspaper, the Observer, as well as the World Affairs Club. A complex woman, Lucile maintained a long-distance courtship for seven years with John Dotha Jones, a man she would eventually marry. After enduring emotional abuse and abandonment, she divorced him in 1940 and never looked back. After burying her beloved brother, Fenton, in 1963, Lucile was determined to maintain the family's house in Denver where her independence only grew. To that end, she hired a neighbor, Herman Dick, to help take care of her basic needs. This arrangement lasted until 1986, ${ }^{3}$ the year the City and County of Denver unceremoniously ripped Lucile from her home, only to place her in a nursing home without notice and consent.

\section{FACING THE UNEXPECTED}

I learned of Lucile Berkeley Buchanan Jones in September 2001, by way of a course I taught on Historical and Contemporary Issues of African American Women for the Women's Studies program (currently Women \& Gender Studies) at the University of Colorado, Boulder. The course usually examines the varying roles Black women played in shaping US history. This time, I wanted to set higher academic expectations by getting students outside the classroom to find primary sources so they could critically examine the history of Black women in Boulder, a predominantly White community tucked away in the foothills of the Rocky Mountains.

When discussing this assignment with colleagues, I endured many jokes about the dearth of Black women, both at the university and in Boulder County. Comments ranged from "You mean the four of you?" to "Where are you going to find them?" Most people simply laughed. Things looked less promising on the 
first day of class. My students (fifteen Whites, four Blacks, and one Latina) knew that Boulder had a very small Black population and wanted to expand the assignment to include Denver, located about twenty-nine miles southeast of Boulder, where they knew for certain they could find Black women. Still, even as I began to doubt the wisdom of the assignment, I dug in and refused to broaden the scope. Considering the movement of Blacks to the West after Reconstruction and the hard-rock mining activities in the nearby mountain communities of Gold Hill, Nederland, Jamestown, and Ward, my instincts and experience led me to believe that Black women likely played important roles at various junctures and, in varying ways, in Boulder County's long history.

\section{GUARDIANS OF THE HISTORY}

In preparing my class for the assignment, I visited several local archives looking for evidence of Black women and their contributions. I first visited the Boulder campus's Heritage Center, located on the third floor of Old Main - the university's first building, completed in 1876 . Operated by the Alumni Association, the Heritage Center is the repository of the accomplishments of the university's renowned, mostly White, alumni-bandleader Glenn Miller; author, screenwriter, and Academy Award winner Dalton Trumbo; US Supreme Court Justice Byron White; the 1958 Miss America pageant winner, Marilyn Van Derbur; and Aurora 7 astronaut M. Scott Carpenter, to name a few.

As of 2001, despite the many accomplished Black alumni, the Heritage Center only celebrated three: Dr. Ruth Cave Flowers (1924), a highly achieving educator and lawyer recognized as the university's first Black graduate; David Bolen (1950), a track star and the university's first Olympic athlete, who went on to become the US ambassador to the German Democratic Republic, Botswana, Lesotho, and Swaziland; and John Wooten (1959), one of the first Black football players recruited to the university and an NFL veteran.

On a subsequent visit to the Heritage Center, the director gave me a copy of an article that appeared in the Rocky Mountain News on June 14, 1993. The headline read: "She was CU's first Black female grad: A pioneer buried without a headstone." The story explicitly heralded Lucile as the university's first Black female graduate. I asked whether anyone at the Heritage Center or at the university's archives had checked into the veracity of the claim. In both cases, I was told "no." How then did this educational achievement come about? Does this story have any historical basis?

As someone skeptical about labels - the "first" as an example-I began to think beyond the label to the unending tension between memory and history that was 
created some eighty-three years ago. As Pierre Nora puts it, "History is the reconstruction, always problematic and incomplete, of what is no longer; it's an intellectual and secular production that calls for analysis and criticism. Memory is a perpetually actual phenomenon, a bond tying us to the eternal present; history is a representation of the past." ${ }^{5}$ Hence, history is ever changing as new phenomenon is discovered that may indeed clash with memory. What was Lucile's cultural and social memory concerning the university and the city of Boulder? What memory remained for the small number of Black students in a racial climate that may have labeled them as Other? How were they able to address the passive or active racism that they faced every day? The few Black students who attended the university in the first two decades of the twentieth century were from Denver and other Colorado cities. Their connection to Boulder's Black community was temporary. Their presence at the university blurred. Once graduated they were wiped off the historical screen. Lucile would be one such example.

However, what the university and the White press missed, the weekly African American newspaper the Denver Star covered and celebrated. Their Boulder News column on December 29, 1917, states, "Miss Alice Norton [a freshman], who is attending the State University, will return to her home at Fort Logan, Saturday, to spend her two weeks' vacation. Miss Lucile Buchanan [a junior], also a student at the university, will visit her parents in Denver during her vacation." The Denver Star confirms that in 1917, Lucile was a student at the university.

Why had Lucile's achievement been ignored? I knew these types of "oversights" are far from exceptional at universities and colleges across the United States. All too often institutions rush to crown the first Black "whatever" without corroborating evidence or asking the right questions. Although historical and cultural preservation efforts are complex, power-laden processes, deliberate decisions are all too often made as to what will be remembered and what will be forgotten.

What was most surprising is that in the 1993 Rocky Mountain News article, Kathy McClurg, a spokesperson for the university, states, "We will correct the mistake in our records and publications, wherever it appears." Eight years later, the university had yet to correct the record. It seemed Lucile's place in the university's history was sealed and that she had been, wittingly or unwittingly, left out.

\section{SETTLING THE DEBATE AND A COMMUNITY'S GUILT}

But who was Lucile Berkeley Buchanan? Several well-meaning colleagues at the university often reminded me that Lucile was "not like a Rosa Parks." The cultural icon associated with the 1955 Montgomery, Alabama, bus boycott. What 
many do not realize is that we all stand on the shoulders of trailblazers who went before us, making it easier for us to follow. Rosa Parks stood on the shoulders of all who refused before to yield their seats on segregated public transportation in Montgomery, Alabama-Aurelia Browder, Susie McDonald, Claudette Colvin, Jo Ann Gibson Robinson, Mary Louise Smith - and the women who preceded those in Montgomery who challenged Jim Crow segregation laws on public transportation and were arrested-Elizabeth Jennings Graham (New York City in 1854); Charlotte Brown (San Francisco, 1863); Pauli Murray and Adelene McBean (Durham, North Carolina, 1940); Irene Morgan (Gloucester County, Virginia, 1944), Maggie Lena Walker (Richmond, Virginia, 1904), and the other women who remain mostly unheralded.

Most could not get beyond the fact that seemingly ordinary people could do extraordinary things while never making it into the historical record. Still, the university's oversight puzzled me, especially in light of the 1993 newspaper article. A colleague and an alumna of the university, Dr. Joanne Arnold, lightheartedly reminded me that Lucile had not bequeathed anything to the university. Thus, fixing the error was not a priority.

Early in my search, I discovered several pieces of evidence corroborating the fact that beginning in the fall of 1916, Lucile was a student at the university. The university had listed Lucile in the Directory of Students and Faculty, 1916-1917, noting that she lived at 821 Mapleton Avenue in a turn-of-the century home, in the Mapleton Hill Historic District. The following year the Directory showed her living at 1304 Pine Street, currently the outdoor parking lot of the Hotel Boulderado.

With these first pieces of evidence, I began to draw some initial impressions about Lucile. Whether by choice, convenience, or necessity, she did not live within the confines of the "Little Rectangle," also known as the "Goss-Grove Ghetto," a four-block area between Nineteenth and Twenty-third Streets and Goss and Water (today Canyon) Streets, which housed Boulder's largest Black community from the end of the nineteenth century until the 1940s. Shortly after her graduation in 1918, the 1922 edition of the University of Colorado Directory of Officers and Graduates, from 1877 to 1921 listed Lucile's address as Slater State Normal in Winston-Salem, a historically Black teacher-training institution in North Carolina. Perhaps the most definitive evidence was a copy of Lucile's official transcript from the Registrar's Office, which confirmed that the university conferred an $A B$ (Artium Baccalaureatus) degree on Lucile on June 5, 1918.

One might think that securing Lucile's place in the university's history would be an easy task, but that was not the case. As word about my research began to spread, I encountered questions typical in an academic environment about my 
research methodologies. But the question from the office of former University of Colorado president Elizabeth Hoffman, while preparing to give a talk to Denver's Black community highlighting the "first" Black student during Black History Month, was most surprising: "Are you sure your research is correct?"

I kept asking myself, do I really want to do this? But what most people didn't know is that my attraction to Lucile's story had nothing to do with being "FIRST." The problem with identifying the first Black graduate at a university that opened in 1877 is that race and ethnic designations were not kept until the mid-1940s and not all graduates were featured in the university's yearbooks, thereby leaving the door open for an ever-changing story. Dismissing the "first" designation, it was the subtitle of the story in the Rocky Mountain News that piqued my curiosity: A pioneer buried without a headstone. I thought of the numerous towns and cities across the United States whose Black bodies had been buried unceremoniously in unmarked graves. Not to mention the practice of burying slaves in unmarked graves. The question left to be settled is, How did a pioneering Colorado woman end up in an unmarked grave in the latter half of the twentieth century?

\section{FEELING IN THE DARK}

Quite accidentally, I fell into what became known as the "Lucile Project." But for those who became involved with the project, there wasn't anything accidental about it. To them, it seemed that Lucile was being "channeled" through me. Mostly, I found the suggestions of "channeling" absurd, and I chuckled every time I heard from family, friends, and especially my research assistants that Lucile had selected me to be her conduit for her story. Yet a series of uncanny coincidences allowed me to whimsically entertain the idea that fate may have had a hand in bringing Lucile and me together, making it impossible to deny the role of chance in the world. These coincidences made me think of Carl Jung's theory of synchronicity, which suggests that although coincidences cannot be explained by cause and effect, there is a relationship between coinciding events that goes beyond mere chance. ${ }^{7}$

To start, Lucile and I shared a connection to the university. She was the first Black woman to graduate from the University of Colorado and the first to major in German. I am the first Black woman to earn tenure at the University of Colorado on the Boulder campus and the first Black woman there to head an academic unit (Women and Gender Studies, 2003-7).

More connections-some obvious, some obscure-surfaced. Five years into the project I discovered that Lucile's husband, John Dotha Jones, and I shared 
the same alma mater, Columbia University in New York City. Next, I learned that Lucile's driver/aide Herman Dick's wife, Ester, was born in Trinidad, Colorado. ${ }^{8}$ I was born on the Caribbean island of Trinidad.

When Lucile died in 1989, she was buried in an unmarked grave at Denver's Fairmount Cemetery. Fred Walsen, ${ }^{9}$ the Samaritan who placed Lucile's name on the tombstone at her burial site in 1998, is a 1939 alumnus of the College of Journalism at the University of Colorado-the same program of study that first hired me as a faculty member. ${ }^{10}$ As more whimsical coincidences surfaced, colleagues and students continued to tease me about inadvertently awakening Lucile's spirit.

\section{REFLECTING ON THE RESEARCH AND THE CHALLENGES}

My research began under the wisdom and guidance of the father of Black history, Carter G. Woodson, who said, "Those who have no record of what their forebears have accomplished lose the inspiration which comes from the teaching of biography and history." ${ }^{11}$ Drawing on personal experiences, I reflected on my own story and the influence of my forebears, strong Black and Latina women who never feared telling their story or articulating their voice, in spite of the personal or political consequences they faced. Thus, I came into this research from a Black feminist and testimonio (first-person narrative) perspective, guided by qualitative research and critical paradigms constructed within the process of self-reflexivity.

Self-reflexivity is characterized by the willingness of the researcher to learn about oneself, one's research purpose, and one's relationship with the social world. ${ }^{12}$ Certainly, this alternative epistemology runs counter to the idea of a "valuefree" framework based on neo-positivism ideas of objective reality and empiricism. As bell hooks states, "Hearing each other's voices, individual thoughts, and sometimes associating these voices with personal experience make us more acutely aware of each other."13

Thus, from the beginning of my research I was acutely aware of Lucile's life on the margins of society (no matter how much she may have struggled to redefine or explain herself to others). I wondered how she worked to defy misconceptions that were held by the majority culture by refusing to be shamed, silenced, or stereotyped. How much did W.E.B. Du Bois's thinking on "double consciousness" and Patricia Hill Collins's "outsider-within" affect Lucile in 1916 as a student at the University of Colorado? A century later, as a Black faculty member on the same campus, I would ask the same question: How is my voice being challenged through the "outsider-within" orthodoxy? 
As the project progressed, I found it increasingly difficult to remain outside the research, whether exploring diaries, love letters, city directories, Sanborn maps of Denver, census data, birth and death certificates, marriage records, draft registration cards from the Civil War through World War II, cemetery records, photos, school transcripts, receipts, or visual recordings. While some of my research may be viewed as orderly and quantifiable, I could not dismiss the inaccuracies caused by human error. For example, the enumerator of the 1885 Colorado State Census lists Lucile and her family as "White." I had to be aware of the unpredictability of the data and the complexities and inaccuracies that presented themselves.

I also felt this research in a personal way. I cringed whenever I was told Lucile was "not like a Rosa Parks," as if all Black women had to be measured by one cultural icon, or when I was told that slavery was different, implying better, in one part of Virginia versus another. Therefore, I had to filter my insights through their meaning-making as a way to improve the quality of the information I was discovering.

Consequently, I supplemented library, archival, and online databases with my observations and interviews conducted in the field: visiting the Big House and walking through the grounds of plantations where Lucile's parents and relatives toiled; visiting homes where Lucile lived and the sites that once marked the schools where she taught; conducting interviews across race, class, age, and gender lines; examining her personal accessories; and visiting the home of Lucile's last two living relatives soon after they committed suicide.

This end of the research led me to feel as if I was on an archaeological dig, entering dark spaces, not always sure what I would discover. It was particularly significant to enter these dark spaces, which often bore her footprints. I saw this process as a rite of passage as I attempted to find meaning in the many cities she called home and from the discoveries I made trekking across ten states (Alabama, Arkansas, California, Illinois, Missouri, Nevada, New York, North Carolina, Texas, and Virginia) in search of Lucile's story.

Along the way, I encountered unique challenges. Tracking potential interviewees was a slow and painstaking process, where in most cases I was racing against time. Frequently, by the time I located a source, the person had died fairly recently. In other cases, the failing memories of potential research participants left me questioning the role of memory in the construction of Lucile's history. Some potential interviewees refused to participate while others were apologetic, explaining to me that they never thought Lucile was important or they would have asked more questions about her. Others said, "We just didn't know, and we 
didn't believe what she told us." Linda Moore, one of the last nurses to care for Lucile, remembered seeing her parents' emancipation papers and taking them to her church in Denver to show the minister and congregants. However, because of her failing memory, she could not recall what happened to the papers after Lucile died.

One of the challenges of writing about a non-celebrity is that you do not have one main repository of the person's papers, which forced me to hunt for materials about Lucile in obscure places and, in many cases, hoping I would gain access to the material. South African writer John Matshikiza once said, "You have to work harder to interest people in the unknown figures of history than you do to interest them in Dave Beckham or J. Y. Stalin." ${ }^{14}$ Unlike Matshikiza, I did not have to work hard to interest people in Lucile's story. But I must admit that I thought recovering Lucile's life would be easier if she were famous or notorious. This turned out not to be the case at all.

For the last four years of Lucile's life, attorney Robert L. Steenrod Jr., the public administrator for the City and County of Denver, was tasked with managing her assets and finances while she lived in a nursing home. My many calls to secure an interview with Steenrod and to get copies of the public records in his possession proved futile. I then solicited the help of Michael Carrigan, an attorney and a member of the university's Board of Regents, hoping that Steenrod would respond to a professional colleague. Carrigan was also unsuccessful. I returned to the court in hopes of finding another alternative. Luckily, a staff member with a degree in history took an interest in Lucile's story, and within two days of my visit I had Lucile's court records. ${ }^{15}$

Bits and pieces of her material possessions were dispersed among several people. It took an astonishing eight years to gain access to what was left of her personal and family memorabilia, photos, letters, shoes, clothing, graduation cap and gown, and other artifacts from one of the previous owners of Lucile's home. For several years, the only people helping me reconstruct Lucile's story were those who knew her as an elder in the Barnum neighborhood in Denver, who knew her through their parents, or who came to know her during the last years of her life. Even with their compassion and love for her, the retelling of what they remembered of Lucile was at times clouded, leaving me with layers of interpretation. Reconstructing Lucile's life history would require me to do what sociologist Erving Goffman suggests - not give any weight to what people say but try instead to triangulate what they say with events and hard data. ${ }^{16}$

My research became a team effort. There were countless people I met along the journey who contributed to the reconstruction of Lucile's story. Throughout 
the project I forged connections with people across racial and class divides, from Colorado to Virginia and various points in-between. Some were the guardians of history, others were reclaiming their own history from distortions and omissions, and some lived on the periphery of society warning me about the do's and don'ts, but they all opened their doors to me, sharing their own historical journeys, and keeping me informed of new discoveries through online exchanges.

The "Lucile Project" became a deeply personal exploration into the life of a forgotten Black woman. As I began to delve into her life, searching for the internal and external forces that shaped Lucile and her family, I became convinced that I had set out to remedy historical amnesia by rescuing a pioneering Black family from obscurity. As a result, I entered into the area of social history, which is concerned with the life and experiences of ordinary people rather than privileged elites. ${ }^{17}$ Even though I managed to maintain a certain detachment, I kept hearing the words of Western historian Shirley A. Leckie, who so eloquently said, "All biography is, in part, autobiographical." 18

Getting at Lucile's story made me acutely aware of the challenges of telling history and telling life stories. Hearing stories about her and reading what she left behind was inspiring. Yet, I longed for an unrehearsed performance piece of her life story that would give voice to the text I was writing. How would she recount her own memories? After eight years of searching for a performative example, I was introduced to Lucile through a seven-minute videotape that was recorded in Denver by Larry Harris and his wife, Doris, in the summer of 1987, when Lucile was 103 years of age.

The video opens with Lucile patiently sitting in a wheelchair in front of the Stovall Care Center, the senior nursing home where she lived. She is smartly dressed, with a white turban hat, a pink and light green floral-patterned dress covering an emerald green blouse, and a small black purse cradled in her lap. The next shot cuts to her sister Laura's gray granite grave marker at Denver's Fairmount Cemetery. I was told by Doris that Lucile was quite familiar with the cemetery since she had an old tradition of Memorial Day visits to decorate family graves with peonies. ${ }^{19}$ Next to Laura's plot the camera pans to Lucile's granite grave marker, which she had purchased for herself as a final resting place thirty-four years earlier. The camera then takes a panoramic view of the monuments in the vicinity before revealing her parents' and siblings' grave sites. before zooming to Lucile sitting in the front seat of a white Buick Skylark parked on the cemetery grounds with the door ajar. Her face is expressive. Her eyebrows add emphasis, jerking sharply up and down, as she begins engaging in conversation with Doris and Larry. 
Although she is blind, her eyes are not at a fixed point. She has a commanding voice that demands attention-she is self-assured in her articulation. As a former teacher, she understands the value of effective classroom management, which she uses as a criteria to judge the nursing home staff and their failure to discipline a resident who she reports as "prowling around and steal[ing] my things." She argues: "They don't discipline her. They don't try to correct her. They just make excuses." Continuing in her teacher role, she asks Larry if he knew any Harrises in New York, a direct reference to her deceased ex-husband's family. She then describes some of the historical events in her maternal family's life, including the family's relationship to Edmund Berkeley (her mother's slave owner and father) and that he was responsible for selecting a husband for her mother and that they were married in the Big House on the grounds of the old plantation. Furthermore, she reveals that Berkeley bought the property where her family's home was located in Denver, and that she was named after her mother's (White) half-sister.

Unable to stand on her own, her body hunched over, she is helped by Doris to her parents' upright headstone, completely shrouded by an evergreen shrub planted some years ago to serve as a memorial to her family's resting place and as a living metaphor for the immortal soul and to the plantation of the same name (Evergreen) where her mother was born.

Lucile gently reaches out to the shrub, occasionally sniffing her hand as she attempts to break off a piece. "It's hard for me to take one out," she said. Doris breaks off a short twig and places it in her hand. After gently touching and sniffing the twig, she places it in her purse to take back to the nursing home. This video, which I was able to obtain almost eight years into the project, took me into Lucile's world, where she continues to display her sharp intellect. An inviting feeling came over me, which made my search for Lucile even more relevant.

Lucile's life, and that of her family, is a portrait of how a family born in slavery survived the Civil War and what one historian has so aptly labeled the "Nadir" of racism in the United States (1890-1920) as Blacks were victimized in everything from housing, transportation, and employment to participation in electoral politics and anti-Black violence. And while Colorado Blacks were not subjected to the anti-Black violence that was pronounced in the southern states, racial disparities still existed as Lucile was denied a teaching position in 1905 in the Denver public school system because of the assumption that White parents would not be comfortable with a Black teacher. She thumbed her nose at Colorado and went to Little Rock, Arkansas, where she launched her teaching career. 
I often wondered how Lucile's family learned to triumph, shape political discourse, create a social life, gain respectability, suffer in silence, and take on or escape the racial disparities confronting Blacks in the American West? As a member of the first generation born after slavery, what ideological premises helped to forge Lucile's character, solidarity, and a sense of civic duty with the plight of the Black masses? Her life and her story is, after all, a story of the United States. A story worth remembering. 